Николай Игоревич Герасимов

Дом русского зарубежья им. А. Солженицына

Отдел культуры Российского Зарубежья

nickgerasimow@yandex.ru
УДК 314.73(=161.1)(497.11)

https://doi.org/10.18485/slavistika.2018.22.2.19

оригинални научни рад

примљено 27.02.2018.

прихваћено за штампу 04.10.2018.

\title{
«БЕЛГРАДСКИЙ» ПЕРИОД В ЖИЗНИ И ТВОРЧЕСТВЕ Е.В. СПЕКТОРСКОГО
}

Автором анализируется «белградский» период в жизни и творчестве Е.В. Спекторского его первые годы в эмиграции. В статье доказывается, что именно в это время произошёл «поворотный момент» в стиле и образе мыслей русского философа - он уделяет много внимания публицистике и почти не занимается академической философией права.

Ключевые слова: русская эмиграция, история русской философии, Белград, Белградский университет, Спекторский.

The author analyzes the "Belgrade" period in E. Spektorsky's life and creative work - his first years in exile. The article proves that it was at this time that a "turning point" occurred in the style and way of thinking of the Russian philosopher - he pays much attention to journalism and almost does not engage in academic philosophy of law.

Key words: Russian emigration, History of Russian philosophy, Belgrade, Belgrade University, Spektorsky.

Время жизни выдающегося философа права русского зарубежья Евгения Васильевича Спекторского (1875-1951) в Белграде стоит понимать как особую эпоху, когда формировались его основные интеллектуальные интуиции, в последующем отразившиеся в культуре русской эмиграции. В строгом смысле именно Белградский университет, его послевоенная атмосфера, его научный коллектив, принявший мыслителя, создали новый творческий «рубеж», когда философ права, долго занимавшийся преимущественно академической философией и юриспруденцией, обратил своё внимание на публицистику и литературоведение.

Жизнь и творчество Е.В. Спекторского в разной степени исследовались ещё с середины XX столетия. В своих классических работах по истории русской философии Н.О. Лосский и В.В. Зеньковский пытались интегрировать идейное наследие мыслителя в общую хронологию развития русской философской мысли. В первом случае Е.В. Спекторскому посвящалось несколько строк в главе «Юристы-философы» (Лосский 1991: 387), во втором - и вовсе два предложения (Зеньковский 2004: 527). Философские воззрения мыслителя неоднократно становились предметом критики со стороны коллег-эмигрантов. Так, со слов В.М. Вишняка, Л.П. Карсавин настаивал на том, что религиозно-философские сочинения проф. Спекторского лишены чувства христианской веры (Вишняк 1925). Примечательно, что положительная оценка творческого наследия мыслителя в публикациях русских философов того времени встречается не в коротких очерках, а в развёрнутых научных статьях (Зеньковский 1975).

Жизнь и творчество Е.В. Спекторского и сейчас является предметом исторических исследований (Михальченко, Ткаченко 2009: 14-24; Михальченко, Ткаченко 
2013: 13-53). Изучается не только научная деятельность философа, но и его публицистика. Исследуются его статьи по теории государства и права, а также политические сочинения (Рутман 2011; Рутман 2012: 270-272, Рутман 2013). Хотя имя ученого неоднократно встречается в историографической литературе, философское наследие Е.В. Спекторского до сих пор остается малоизученным в сравнении с работами Н.А. Бердяева, Л.И. Шестова, И.А. Ильина и многих других. Одна часть историко-философских публикаций посвящена его до-эмигрантскому периоду (Герасимов 2016), другая - общему интеллектуальному портрету (Щеглова, Щеглов 1997). Отдельная группа научных публикаций - библиографические справки (Ермичёв 2006) и культурологические очерки (Щеглов 2009, Щученко 1998), преследующие цель не столько вскрыть глубинные интеллектуальные интуиции Е.В. Спекторского, сколько дать эмпирический материал для целенаправленных историко-философских исследований. Особо стоит отметить многочисленные исторические работы С.И. Михальченко и Е.В. Ткаченко, проливающие свет на историю жизни проф. Спекторского в контексте эпохи (Михальченко 2011, 2015, Михальченко, Ткаченко 2009, 2009а, 2011, 2013, 2014).

Массив неизданных рукописей труднодоступен для отечественных исследователей, так как наиболее ценные архивные документы по творчеству Е.В. Спекторского располагаются в Бахметьевском архиве Колумбийского университета в Нью-Йорке. На сегодняшний день защищены всего две диссертационные работы по истории жизни и деятельности Е.В. Спекторского, имеющие отношение к его философскому творчеству. Одна из работ на соискание степени кандидата исторических наук принадлежит Е.В. Ткаченко (Ткаченко 2008), другая - на соискание степени кандидата юридических наук - В.Г. Рутман (Рутман 2013). Таким образом, нет ни одного специального диссертационного историко-философского исследования, посвященного идейному наследию мыслителя. Всё вышеуказанное говорит о том, что современная наука лишь начинает систематизировать эволюцию философских воззрений Е.В. Спекторского, когда периодизация творчества «привязывается» не только к эмигрантскому пути философа, но и к истории развития его умонастроения. Такая интеллектуальная история жизни мыслителя включает в себя «переоценку ценностей», «экзистенциальную смерть» и другие поворотные моменты, прямым образом влияющие на идейные ориентиры выдающегося философа права.

Профессиональная сфера деятельности Е.В. Спекторского - не просто юридические науки, а конкретно философия права. Автор данной статьи считает, что идейное наследие мыслителя можно интерпретировать только сквозь призму философии. Другие интеллектуальные «оптики» хотя и дают представление о творческой деятельности русского профессора-эмигранта, по своему устройству не способны создать ясное отражение его духовных поисков. В данной работе на примере анализа «Белградского» периода творчества осуществляется историко-философская интерпретация идейного наследия Е.В. Спекторского. Автор исследования использует текстологический и историко-философский методы, а также метод историко-философской когнитивной реконструкции.

Е.В. Спекторский (15 октября 1875 года, Острог - 3 марта 1951 года, НьюЙорк) родился в семье правоведа и судебного следователя В.А. Спекторского, окончил Императорский Варшавский университет (в 1898 г.). Под руковод-

Славистика XXII/2 (2018) 
ством А.Л. Блока (отца поэта А.А. Блока) защитил диссертацию «Жан Жак Руссо как политический писатель» и получил степень кандидата права. Памяти Блока написал статью «Александр Львович Блок, государствовед и философ» (Спекторский 1911).

В 1898 - 1901 гг. Е.В. Спекторский работал в Варшавском университете, 1901 - 1903 гг. специализировался в университетах в Париже, Геттингене, Гейдельберге и Берлине, в 1903 г. был приват-доцентом кафедры энциклопедии и истории философии Варшавского университета, в 1910 г. получил степень магистра права Юрьевского (Дерптского) университета.

В 1913 г. Е.В. Спекторский был избран профессором Университета св. Владимира в Киеве, а также преподавал на Женских высших курсах. В 1917 г. в Московском университете получил степень доктора государственного права. С этого момента начинается его карьерный рост. В 1918 г. он не только становится ректором Киевского университета, но и главой Киевского философского общества. В 1920 г. русский мыслитель через Одессу уехал из России в Королевство сербов, хорватов и словенцев (КСХС, с 1929 г. - Югославия) не только потому, что хотел избежать репрессий как деятель, несогласный с политикой большевиков, но и как человек, который мог быть заподозрен в сотрудничестве с А.И. Деникиным (в 1919 г. при взятии Киева А.И. Деникин назначил проф. Спекторского попечителем Киевского учебного округа, но тот так и не приступил к исполнению обязанностей) (Зеньковский 2011).

Мыслителю было необходимо обустроить свою жизнь, Белградский же университет прекрасно понимал, что новообразованное государство нуждается в крепких правовых институтах, что стране необходимы новые кадры, особенно специалисты, которые могли бы способствовать воспитанию новых юристов. Стремительный рост количества студентов высшей школы требовал всё большое и больше число квалифицированных преподавателей. Е.В. Спекторский первоначально был принят на работу как «гонорарный профессор» (Козлитин 2016: 319) по кафедре истории философии права (перевод произошёл уже после 1926 г., когда русская профессура могла получать подданство Югославии) (Михальченко, Ткаченко 2009: 14-24).

В первое время русское зарубежье осмысливало трагедию революции и изгнание как временное явление, за которым обязательно последует возвращение домой. Мнение, что власть большевиков окончательно утвердится в России, тогда было непопулярным. Если возвращение неминуемо, то для нового государства потребуются новые политические связи. КСХС ожидало, что сотрудничество будет иметь следующий порядок: русская профессура помогает воссозданию высшего учебного образования, затем возвращается в Россию, где начинает «поднимать из пепла» собственные правовые и образовательные институции, которые не смогли бы воплотиться в жизнь без помощи КСХС - таким образом, будущий крепкий политический союз казался неминуем.

В том же 1920 г. в Белграде образовалось Общество русских учёных, председателем которого был избран Е.В. Спекторский. Уже к 1921 г. в Обществе произошёл раскол: Ф.В. Тарановский обвинил Е.В. Спекторского в том, что тот «закрывает глаза» на то, что в организации есть члены бывшего гетманского 
Правительства (в частности, В.В. Зеньковский). Никакого ответа не последовало. Е.В. Спекторский дал возможность части русской профессуры создать собственную Русскую академическую группу (в составе 20 человек) (Михальченко, Ткаченко: 2009: 31).

Затем наступило время, когда мыслитель покинул Белград (впрочем, не прекращая связь с Белградским университетом) и уехал в 1924 г. работать в недавно образовавшийся Русский юридический факультет в Праге (по приглашению его основателя П.И . Новгородцева) (Герасимов 2018). Концепция учреждения предполагала построить фундаментальное юридическое образование по модели российского университетского устава 1884 г. с акцентом на философию права. Предполагалось, что выпускники этого факультета должны были стать будущими «строителями» правовой системы России. В 1927 г. Е.В. Спекторский даже становится деканом этого факультета. Однако, в 1928 г. наступает закат «русских акций», поэтому финансирование учреждения резко сокращается. В том же году Е.В Спекторский вновь возвращается в Белград (Михальченко, Ткаченко 2009: 18) (или в 1927? Источник). В основе таких перемен лежали не только материальные причины. Мейснер Д. отмечал, что между русскими и чехами было некоторое «недопонимание», в то время как диалог между русскими и сербами как раз обладал степенью прозрачности и взаимного уважения, необходимого для полноценного взаимного сотрудничества (Мейснер 1966: 136-137).

23 июня 1928 г. состоялось первое собрание Русского научного института в Белграде, председателем которого был избран Е.В. Спекторский. Е.В. Ткаченко отмечает, что «Спекторским были определены основные задачи этого заведения - "1) разработка научных проблем с применением русских методов и традиций”; 2) изучение прошлого и настоящего России". Кроме того, целью института являлось “подготовка молодых ученых и печатных изданий”» (Ткаченко 2008: 108). Мыслитель с успехом руководит институтом и продолжает свои научные исследования. Тем не менее, уже в 1930 г. Е.В. Спекторский переезжает в Любляну, где остаётся работать в местном университете до 1945 г. С 1945 г. он находится на территории Италии, где два года проводит в лагерях для «перемещенных лиц». В 1947 г. приглашен в Нью-Йорк для работы в СвятоВладимирской православной духовной семинарии. Проф. Спекторский также был первым председателем Русской академической группы в США вплоть до своей смерти.

В чём состоит особенность «белградского» периода в жизни и творчестве мыслителя? До эмиграции Е.В. Спекторский был известен как академический философ и юрист, историк социальных наук, автор фундаментального труда «Проблема социальной физики в XVIII столетии» (Спекторский 2006). С первых же лет пребывания в изгнании научные интересы мыслителя, а также стиль его письма резко меняются - он посвящает себя публицистическим работам, в которых прежнее бесстрастное описание тех или иных интеллектуальных сюжетов исчезает, начинает преобладать острополемический стиль. На смену аргументированным доводам с опорой на широкую фактическую базу приходят неподтверждённые гипотезы, догадки и смутные предположения. В философском смысле Е.В. Спекторский окончательно «рвёт отношения» с неокантианской методологией, к которой он хоть и относился критически, в то же время 
постоянно использовал её концептуальный инструментарий. В новых сочинениях философа его «генетический метод» исследования существует лишь формально. Аккуратная феноменологическая позиция в отношении христианского номинализма и реализма, свойственная ранним работам Е.В. Спекторского, в его «белградском» творчестве как будто исчезает. Доминирует христианский трансцендентализм (в самом исконном схоластическом смысле). Здесь, в Белграде, мыслитель проявляет большой интерес к устройству религиозной жизни, он посещает церкви и храмы (Михальченко 2013). Можно было бы предположить, что интерес Е.В. Спекторского к социальной организации конфессиональной культуры был всего лишь формой научного исследования, когда учёный «выходит из кабинета» навстречу «живым фактам», и не имеет ничего общего с личными убеждениями, но об обратном говорит отмеченный С.И. Михальченко фрагмент в неопубликованных «Воспоминаниях» русского эмигранта, который описывает ситуацию, когда мыслитель испытал глубокое эмоциональное раздражение при входе в католический храм (Михальченко 2013a). Именно в Белграде Е.В. Спекторский неожиданно предстаёт перед публикой как публицист, провоцирующий своих читателей на дискуссию. Увлечение всеобщей историей права также «уходит на второй план»-в центре внимания мыслителя оказывается русская культура, православное вероучение, проблема диалога этносов и политический радикализм. Личная позиция проф. Спекторского поступательно вытесняет его стремление работать с фактами объективно.

В своей статье «Пётр Великий и мы» Е.В. Спекторский полемизирует с Л.П. Карсавиным, утверждавшим, что политика Петра I схожа с современной большевистской политикой. Е.В. Спекторский принципиально не соглашается со своим оппонентом и придерживается мнения, что большевизм - явление, не имеющее аналогов в русской истории. В этой же статье он утверждает, что история России, как и других стран состоит из смены «органических» и «критических» эпох. Если «органическая» фаза развития истории предполагает гармонию, слаженность тех или иных сфер культуры, то «критическая» - радикальный пересмотр всего предыдущего наследия. Россия Петра I - это и есть «критическая» фаза, но она по своей природе не имеет ничего общего с большевизмом. (Спекторский 1925). С проф. Спекторским можно было бы даже согласиться, но отсутствие фактической базы в сумме с острополемической формой изложения говорят лишь о том, что мыслителю важны не факты, а диалог мнений.

Вышедшее в 1925 г. в Праге сочинение «Христианство и культура» окончательно приводит Е.В. Спекторского к христианскому философскому миросозерцанию, понимаемому им как «трансцедентный идеализм». В этой работе мыслитель не скрывает своего пренебрежительного отношения к академическому толкованию христианской веры, упоминая в тексте «прилизанные философские системы, придуманные профессорами и комментируемые профессорами» (Спекторский 2013)

В 1930 г. в Белграде выходит сборник, посвящённый памяти св. Владимира, в котором также есть статья Е.В. Спекторского, где мыслитель отстаивает мнение, что понятие «народ» относится не к сфере этнологии, а к сфере этики. Аргументы в пользу своей позиции он не приводит. С крещения Руси начинается история русского народа. По мнению Е.В. Спекторского, крещение 
было абсолютно ненасильственным и глубоко этическим по своему содержанию. Именно православие спасло славянские народы от культуры азиатских кочевников. Именно православие также спасло и католическую Европу, остановив орды кочевых языческих племён (Спекторский 1930). В вышедшей в то же время статье «Християнство и кризита на съвременната култура» Е.В. Спекторский продолжает настаивать на том, что именно христианство способно вывести человечество из духовного кризиса (Спекторский 1930). В другой статье, написанной годами позже, Е.В. Спекторский, продолжая отстаивать мнение, что крещение Руси было абсолютно ненасильственным, выделяет в истории России трёх правителей, чья политика наиболее существенно повлияло на русскую культуру: князь Владимир Святославович, Пётр I и Александр II. Именно благодаря князю Владимиру Россия выбрала, по его словам, «святость, а не рыцарство» (Спекторский 1938). В историософском смысле проф. Спекторский является продолжателем идей христианского мессианизма, подобному Н.А. Бердяеву, И.А. Ильину и другим русским философам-эмигрантам того времени. Христианский мессианизм в его работах существует в оптике исторического оптимизма, несмотря на констатацию существующего в обществе духовного кризиса. Эсхатологизм, наблюдаемый в работах многих философов того времени, чужд Е.В. Спекторскому. Для мыслителя христианство в будущем с необходимостью утвердится как общая для всей культуры идейная парадигма.

Е.В. Спекторский не оставляет в стороне и русскую литературу. Написанную в Белграде статью «Заветы Пушкина» его коллеги из Праги с охотой публикуют в «Пушкинском сборнике» 1929 г. В этой работе мыслитель отстаивает мнение, что вся поэзия А.С. Пушкина суть пророчество: Россию настигают духовные и политические катастрофы один раз каждое столетие. Власть самозванца всегда краткосрочна, смутные времена, так или иначе, заканчиваются. Перечисляя «заветы Пушкина», он останавливается на трёх основных:

1. Не унывать («Неунывающая бодрость, несмотря ни на какие невзгоды»). Противопоставляя А.С. Пушкина Ю.М. Лермонтову, он приходит к выводу, что первый - поэт бодрости, в то время как второй - «поэт грусти» (слова историка В.О. Ключевского). Бодрость есть результат конфликта между хаосом в жизни и стремлением человека преодолеть этот хаос в своём творчестве;

2. Трудиться и не терять любопытства. Культура России и есть культура любопытства - именно так она интегрировалась в общий европейский культурный ландшафт;

3. Необходимость хранить русскую культуру, оберегать её. Ещё задолго до расцвета русской философской мысли А.С. Пушкин, по словам Е.В. Спекторского, жалел, что в России ещё нет своего «метафизического языка». Метафизический язык способствует тому, чтобы культурные ценности не уничтожались в ходе чужой культурной экспансии. (Спекторский 1998)

В это же время Е.В. Спекторский пишет о Ф.М. Достоевском и А.П. Чехове. (Спекторский 1923, 1930)

В это переломное время академизм мыслителя ещё не был вытеснен его страстью к публицистическому творчеству. Написанная в 1928 г. работа «Предмет и 
отношение в общественных науках» является прямым продолжением его исследований по философии права и истории социальных наук (Спекторский 1929). Немаловажной является и его работа над «Записками Русского научного института в Белграде» (17 выпусков), а также фундаментальный труд «Материалы для библиографии русских научных трудов за рубежом» (Спекторский 1931, 1941). Кроме того, если верить словенскому правоведу Marijan Pavčnik, то в 1931-1932 гг. проф. Спекторский работал над двухтомной «Историей социальной философии» («Zgodovina socijalne filozofije»), которая должна была быть издана в Любляне, в издательстве «Slovenska Matica» (Pavčnik 2016).

Во время своей работы в Люблянском университете Е.В. Спекторский осмысливает природу русского либерализма, итогом чего стало большое эссе, изданное в 1935 г. (Спекторский 1935). Пожалуй, среди общего числа изданных философских работ, в которых наблюдается связь русского эмигранта с его дореволюционной научной деятельностью, именно это сочинение заслуживает особого внимания. В «Либерализме» проявляется и общее стилистическое единство с до-эмигрантским творчеством мыслителя, и особенность системного историко-философского анализа, когда те или иные интеллектуальные сюжеты описываются им в оптике генезиса, т.е. в свете такой философской установки, когда сами идеи являются порождениями друг друга, а не только результатами умственной работы тех или иных философов, литераторов и учёных. Е.В. Спекторский выделяет три смысла свободы:

Социальный положительный смысл свободы, подразумевающий борьбу за свободу других - это и есть либерализм. Тем не менее, либерализм хоть и близок к «левой» политической мысли, в своём содержании предполагает коммуникативную («меновую») справедливость - в этом проявляется крайний индивидуализм либерализма, основанный на узком прочтении конфликта между государством и личностью. Либерализм основывается на оптимистическом взгляде на человеческую природу - в этом он совершает крайнюю ошибку, как и анархизм. Исторически либерализм является источником всех освободительных идеологий (от либеральной демократии до социал-демократии и анархосиндикализма) - в этом его ценность как культурного явления.

Несмотря на то что, по словам С.И. Михальченко, Е.В. Спекторский уже к 1929 г. публиковался в основном на сербском, а не на русском языке (Михальченко, Ткаченко: 19), констатировать сильное влияние русского эмигранта на югославское академическое сообщество вряд ли представляется возможным. Открыв в себе публициста, проф. Спекторский искал диалог с другими представителями русского интеллектуального зарубежья. Находясь в духовном поиске новых смысловых ориентиров, мыслитель надеялся, что эмигрантское сообщество сможет выработать в себе основы для дальнейшей жизни вдали от Родины.

Жизнь и работа Е.В. Спекторского в Белграде была яркой на события. Именно в Белграде академизм мыслителя впервые стал вытесняться публицистическими сочинениями - благодаря им проф. Спекторский не только связал себя узами общения с другими эмигрантами, переживающими глубокий личностный кризис, но и нашёл благодарных читателей среди русской научной профессуры Югославии. На материале русской литературы, истории и политической мысли он как будто пытался понять своё место в сложившейся культуре межвоенной 
Европы. «Белградский» период жизни и творчества Е.В. Спекторского - это начало его пути как эмигранта, как человека, который только-только начинает осознавать себя в ещё не до конца понятой роли скитальца.

\section{Использованная литература}

Вишняк, М.В. «Две свободы». Современные записки 24, 1925: 331-334.

Герасимов, Н.И. «Е.В. Спекторский как историк „социальной физики“». История философии. Т.2, 1, 2016: 116-127.

Герасимов, Н.И. «Белградский период» творчества Е.В. Спекторского. [В:] Тезисы Международной конференции студентов, аспирантов и молодых ученых «Ломоносов 2018». МГУ им. М.В. Ломоносова, секция «История русской философии» на интернет-портале «Ломоносов»] https://lomonosov-msu. ru/archive/Lomonosov_2018/data/13446/69555_uid880_report.pdf 24.11.2018.

Ермичев, А.А. Е.В. Спекторский (1875-1951). Биобиблиографическая справка / Спекторский Е.В. Проблема социальной физики в XVII столетии. Т.2. СанктПетербург: Наука, 2006, 506-523.

Спекторски, Евгеније В. Хришћанска етика. Врњачка Бања: Братство Св. Симеона Мироточивог, 2003.

Зеньковский, В.В. «Е.В. Спекторский». [В:] Н.П. Полторацкий (ред.) Русская религиозно-философская мысль ХХ века. Питтсбург: Отдел славян. яз. и лит. Питтсбург. ун-та, 1975, 317-321.

Зеньковский, В.В. История русской философии. Ростов-на-Дону: Феникс, 2004.

Зеньковский, В.В. «Пять месяцев у власти. Воспоминания». [В:] М.А. Колеров (ред.) Исследования по истории русской мысли. Т.15. Москва: Regnum, 2011, 453.

Козлитин, В.Д. Русская и украинская эмиграция в Югославии (1919-1945). Харьков: Каравела-РА, 1996.

Лосский, Н.О. История русской философии. Москва: Советский писатель, 1991.

Мейснер, Д. Миражи и действительность: Записки эмигранта. Москва: Изд-во АПН, 1966.

Михальченко, С.И. «Воспоминания» Е.В. Спекторского о религиозной жизни южных славян 1920-х - 1930-х годов. Религиоведение 4, $2013 \mathrm{a} ; 168$.

Михальченко, С.И. «Документы Е.В. Спекторского в архиве Института Восточной Европы Бременского университета». Отечественные архивы 6, 2011: 64-68.

Михальченко, С.И. «Политическая межконфессиональная жизнь межвоенной Югославии по мемуарам Е.В. Спекторского». Научные ведомости Белгородского государственного университета. Серия: История. Политология 1 (144) 2013: 120-126.

Михальченко, С.И. «Словения 1930-х голов в неопубликованных мемуарах Е.В. Спекторского». Пространство и время 1-2, 2015: 252-256.

Михальченко, С.И. Е.В. Ткаченко. «Е.В. Спекторский в эмиграции (19201951)». Славяноведение 1, 2009: 14-24.

Михальченко, С.И., Е.В. Ткаченко. Американский период в жизни Е.В. Спекторского // Проблемы истории Центральной и Восточной Европы. Сборник научных статей. НИИ фундаментальных и прикладных исследований, Центр славяноведения. 2009. С.75-81; 
Михальченко, С.И., Е.В. Ткаченко. «Е.В. Спекторский в эмиграции (19201951)» Славяноведение 1, 2009а: 14-24.

Михальченко, С.И., Е.В. Ткаченко. «Евгений Васильевич Спекторский: общественный деятель и ученый». Вопросы истории 1, 2013: 31-53.

Михальченко, С.И., Е.В. Ткаченко. «Мемуары Е.В. Спекторского как источник по истории Варшавского университета конца XIX-XX вв.». Вестник Брянского государственного университета 2, 2014: 98-101.

Рутман, В.Г. Государственно-правовые воззрения Е.В. Спекторского: автотореф. дис... канд. юрид. наук. Белгород, 2013.

Рутман, В.Г. «Е. В. Спекторский о трех смыслах демократии». Пробелы в российском законодательстве 2, 2012: 270-272.

Рутман, В.Г. «Конституционное государство в представлениях Е.В. Спекторского». Исторические, философские, политические и юридические науки, культурология и искусствоведение. Вопросы теории и практики. Тамбов, 8 (14), 2011: 169-171.

Спекторский, Е.В. Александр Львович Блок, государствовед и философ. Варшава: Типография Варшавского учебного округа, 1911.

Спекторский, Е.В. «Достоевский как публицист». Русская мысль, Берлин IXXIL, 1923: 246-262.

Спекторский, Е.В. Заветы Пушкина // Заветы Пушкина. М.: Эллис лак, 1998, 203-226.

Спекторский, Е.В. Либерализм. Любляна: Нова Штампарија, 1935.

Спекторский, Е.В. Материалы для библиографии русских научных трудов за рубежом. Т.1. Белград, 1931. Т.ІІ, 1941.

Спекторский, Е.В. Номинализм и реализм в общественных науках. М.: Тип. Г. Лисснера и Д. Собко, 1915.

Спекторский, Е.В. «Пётр Великий и мы». Благосвет, Новый Сад, Сб. №1, 1925, $53-56$

Спекторский, Е.В. «Предмет и отношение в общественных науках». Труды IV съезд русской академической организации в Белграде. Белград, 1929.

Спекторский, Е.В. Проблема социальной физики в XVII столетии. T.1-2. СанктПетербург: Наука, 2006.

Спекторский, Е.В. «Св. Владимир и русская культура». Сборник в память св. равноапостольного кн. Владимира, Белград, 1930, 26-28

Спекторский, Е.В. «Своеобразие крещения Руси». Владимирский сборник. В память 950 летию крещения Руси, Белград, 1938, 56.

Спекторский, Е.В. Христианство и культура. Москва: Центр стратегической конъюнктуры, 2013.

Спекторский, Е.В. «Християнство и кризита на съвременната култура». Философски преглед. 1930, Кн. I, С. 1.

Спекторский, Е.В. Чехов. Белград: Изд-ние Н.З. Рыбинского, 1930.

Ткаченко, Е.В. Научно-образовательная деятельность и общественно-политические взгляды Е.В. Спекторского: дис. ... канд. истор. наук. Брянский государственный университет, Брянск, 2008.

Щеглова, Л.В. В.В. Щеглов. Философский портрет Е.В. Спекторского // Вестник Московского университета. Серия 7: Философия,1997. №4. С.3-12. 
Щеглов В.В. «Христианская интерпретация культуры в наследии Е.В. Спекторского». Известия Волгоградского государственного педагогического университета 8 (42), 2009, 4-8.

Щученко, В.А. «Некоторые идеи христианской культурологии Е.В. Спекторского в свете современного общественного развития». Православие в русской культуре. Санкт-Петербург, 1998, 6-13.

Pavčnik, M. $20^{\text {th }}$ Century Philosophy and Law in Slovenia // A treatise of legal philosophy andgeneral jurisprudence. Bologna: Springer, 2016. Vol. 12. Legal philosophy in Twenties Centuary: The Civil Law World pp. 674-680.

\section{Николај Игоревич Герасимов}

\section{„БЕОГРАДСКИ” ПЕРИОД У ЖИВОТУ И СТВАРАЛАШТВУ \\ J.В. СПЕКТОРСКОГ}

\section{Резиме}

„Београдски” период живота и стваралаштва J. В. Спекторског савремени истраживачи још увек разматрају у општем контексту „емигрантског” пута овог мислиоца не обраћајући пажњу на промене које су се десиле у његовом интелектуалном опису. Међутим, прве године које је Спекторски провео далеко од Русије значајно су утицале на природу његовог стваралаштва. Академизам, који је одликовао његов стил, полако је почео да се повлачи пред публицистиком. Ако је пре емиграције филозоф био познат научној јавности као претежно кабинетски научник, који сав свој напор улаже у истраживање кључних историјско-филозофских и филозофско-правних питања, онда се већ у Београду његова репутација мења - J. В. Спекторски објављује бројне полемике у којима инсистира на идеји хришћанског трансцедентализма и месијанизма. Иако је питање порекла социјалних наука још увек представљало један од кључних праваца истраживања овог мислиоца, лична духовна криза Спекторског га је подстакла да издвоји нове смисаоне оријентире - у својим публикацијама из тог периода филозоф је настојао да ступи у жив дијалог са емигрантским круговима и надао се да ће руска интелектуална емиграција изнедрити нове облике културне сарадње.

Кључне речи: руска емиграција, историја руске филозофије, Београд, Универзитет у Београду, Спекторски. 